PRODUCTION

ENGINEERING ARCHIVES
2014, Vol. 4, No. 3, pp 18-21

ISSN 2353-5156 (print version)

ISSN (online version)

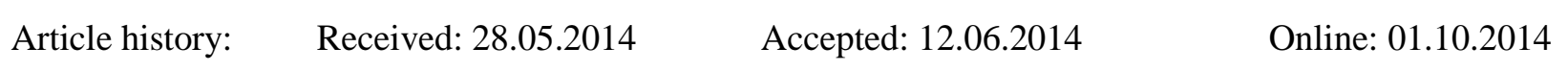

\title{
Fatigue properties of the HSLA steel in high and ultra-high cycle region
}

\author{
Robert Ulewicz ${ }^{1}$, František Nový ${ }^{2}$, Magdalena Mazur ${ }^{1}$, Pawel Szataniak $^{3}$ \\ ${ }^{1}$ Institiute of Production Engineering, Czestochowa University of Technology, ul. Armii Krajowej 19B, 42-201 Czestochowa, Poland, \\ e-mail: ulewicz@ zim.pcz.pl, mazur.m@zim.pcz.pl \\ ${ }^{2}$ Department of Materials Engineering, Faculty of Mechanical Engineering, University of Žilina, Univerzitná 1, 01026 Žilina, Slovak \\ Republik, e-mail: frantisek.novy@fstroj.uniza.sk \\ 3 WIELTON S.A., ul. Baranowskiego 10A, 98-300 Wieluń, Poland, e-mail: pawelszataniak@pamapol.com.pl
}

\begin{abstract}
This work presents a study of the fatigue properties in the example of Swedish steel Hardox 400. Fatigue tests were carried out in the area of high and ultra-high cycle region. From the practical point of view the durability of some components in the automotive industry and similar technical applications such as special semitrailers ranges between $10^{8}$ and $10^{10}$ cycles. But, only a few experimental results beyond $10^{7}$ cycles are available now. The main objective of this research was to provide independent results to the company which uses Hardox steel in the construction of semitrailers. Selected mechanical and fatigue tests were carried out with the aim to study fatigue properties of Hardox steel. Based on the obtained experimental results the fatigue properties of this still not well recognized type of steel are discussed.
\end{abstract}

Key words - HSLA steels, Hardox 400; ultra-high-cycle fatigue; S-N curve

\section{Introduction}

Fatigue strength is the ability of material to resist the fatigue process. Attempts of metal fatigue rely on repeated burdening of the sample, causing alternating stress states. The variability of stress at the time $\tau$ is characterized by a frequency $f$, the size and type of stress and asymmetry coefficient of R cycle. Increased fatigue strength of material is gaining importance in solving the general problem of improving the reliability and durability of modern machines and structures. Analysis of causes of failures of machine elements and structures indicates that the majority of more than $90 \%$ of all cases is due to fatigue cracking. At the actual operation, the components and constructions are loaded mainly by repeating loading that could lead to the ultimate state, fatigue fracture in the final consequence (RADEK N. 2012). If it is assumed that the construction material will be repeatedly cyclically loaded in the operation, then it will be necessary to determine very complex fatigue characteristics for the given operation conditions. It means to state experimentally the concrete values from the area of the low-cyclic, highcyclic and ultra-high-cyclic fatigue for the construction material and by respecting of the philosophy of the admissible defects, also the values of fracture mechanics (Tillová E., Chalupová M. 2009, Mazur M., ULEWICZ R., BORKOWSKI S., NOVY F. 2012).

To determine the fatigue characteristics mentioned above experimentally, the normal frequencies are applied in the range from $\mathrm{f} \approx 10 \mathrm{~Hz}$ to $\mathrm{f} \approx 200 \mathrm{~Hz}$, which is time demanding and expensive. This statement emphasizes the fact, that fatigue fractures occur even after a 
billion cycles and more (KOSTER M. et.all 2010) and the stated, conventional criteria (BOKŮVKA O. et.all 2008) do not fulfill the requirements for the safety and evaluation of components and constructions endurance. Sakai T., Takeda M., Shiozava K., Ochi Y., Nakajima M., Nakamura T., Oguma N., Masuda S., Nishijima S., Tanaka Y., Naito T., Ueda H., Kikuchi M., Bathias C., Bonis J., Asami K., Hironaga M. stated f. e. the decreasing of the fatigue characteristics, dependence $\sigma_{a}=f(N)$ beyond conventional limit of cycles $\mathrm{N}_{\mathrm{f}}=10^{7}$, first of in the high strength and surface hardened steels (for example Hardox steel) (SAKAI T. et.all 1999, MASUDA S. et.all 1986, NAITO T. et.all 1984, BATHIAS C., Bonis J. 1998, ASAMI K., HIRONAGA M. 1994). One of the possible directions is the application of experimental methods of high frequency cyclic loading to determination of the fatigue properties in construction materials. These experimental methods are progressive without question, with a wide future application, they are very time and economically effective (BOKUVKA O. et.all 2002, DORAZIL E. 1991). Economical factors are also very important for the producers of semi-trailers where we observe actions aimed at significant reduction in the weight of semitrailers by application of new steel grades, especially micro alloyed (HSLA- Hight Strength Low Alloy) of the structure: Ferritic, FerriticPearlitic, ferRite-Bainitic, Bainitic and Bartenit Tempered. These group of steels bring specific combinations of mechanical parameters and abilities of dynamic reinforcement together with keeping the tendency to ductile fracture in a wide range of working temperatures (Hanus P., Konečný M. 2014).

\section{Materials}

The structural material, which is namely HSLA steel Hardox 400, was used for fatigue tests. The steel is produced by a Swedish metallurgic company SSAB. This steel is used for structural components of semitrailers of tipper type by Wielton S.A. Company. Hardox 400 is an abrasion resistant steel with a nominal hardness of $400 \mathrm{HBW}$. Typical applications are components and structures subject to wear. Chemical composition and mechanical properties are shown in Table 1.
Table 1. Chemical composition (in wt.\%) and mechanical properties, HSLA steel Hardox 400

\begin{tabular}{|ccccccccc|}
\hline \multicolumn{10}{|c|}{ Hardox 400 } \\
\hline $\mathrm{C}$ & $\mathrm{Si}$ & $\mathrm{Mn}$ & $\mathrm{P}$ & $\mathrm{S}$ & $\mathrm{Cr}$ & $\mathrm{Ni}$ & $\mathrm{Mo}$ & $\mathrm{B}$ \\
0.13 & 0.30 & 0.95 & 0.012 & 0.002 & 0.25 & 0.06 & 0.04 & 0.002 \\
\hline \multicolumn{2}{|c|}{$\mathbf{R}_{\mathbf{e}}[\mathrm{MPa}]$} & \multicolumn{2}{|c|}{$\mathbf{R}_{\mathrm{m}}[\mathrm{MPa}]$} & $\mathbf{A 5}[\%]$ & $\mathbf{H B W}$ \\
1150 & & 1350 & & 11 & 410 \\
\hline
\end{tabular}

The increase in the hardening of the steel causes the carbide forming elements $(\mathrm{Cr}, \mathrm{Mo})$ delaying tempering processes. For an intensification of the effect of chromium and molybdenum (such as Hardox steels) are used together. Moreover, the presence of molybdenum in the range of $0.25 \div 0.60 \%$ (for other types of steel Hardox) has a positive effect of secondary hardness and prevents irreversible temper brittleness at 250 $\div 400{ }^{\circ} \mathrm{C}$. The presence of molybdenum (min $0.20 \%$ $\mathrm{Mo}$ ) is all the more important since chromium (like phosphorus and other trace additives) will increase the tendency to temper brittleness. Furthermore, nickel and manganese in the presence of chromium contribute to this process. The microstructure of Hardox steel is shown in Fig. 1.

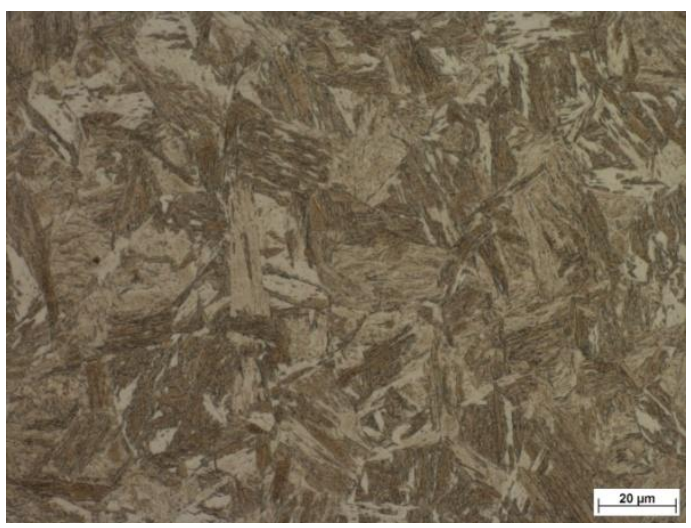

Fig. 1. Microstructure of Hardox 400 steel

Metallographic analysis was carried out by means of an optical microscope NEOPHOT 32. As a result of the analysis of microstructure it was found that Hardox 400 steel has a structure of tempered Martensite. Steels that have been tested are characterized by coarsely acicular Martensitic structure.

\section{Experimental procedure and result}


Rotating bending, tension-compression and high frequency tension-compression loading were employed to investigate fatigue properties of Hardox 400, respectively. The loading system was rotating bending equipment operating at the frequency of $40 \mathrm{~Hz}$. The stress ratio of $\mathrm{R}=-1$ was chosen. Both experiments were performed at the ambient temperature. During the test the working part of the specimens was cooled by means of fans. To determine the material's fatigue strength 10 specimens of Hardox 400 steel underwent the high cycle fatigue test. Results of the comparative material were received from tests performed in identical conditions. The results obtained in a Wöhler curve are shown in Figure 2.

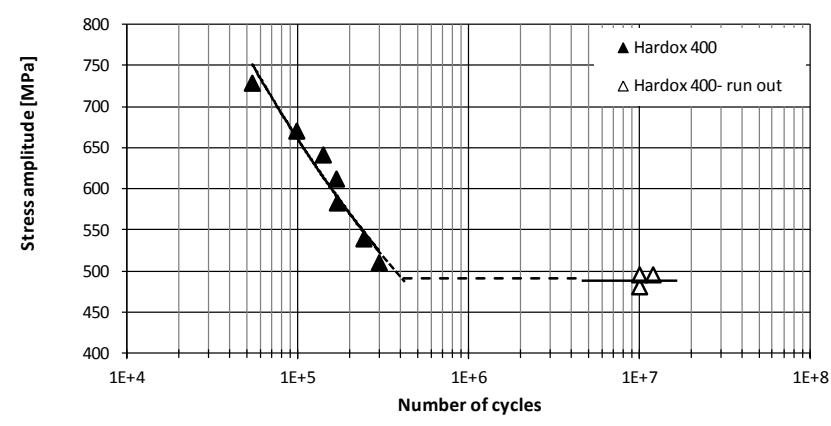

Fig. 2. Stress amplitude $\sigma_{a} v$ s. number of cycles $N$ for Hardox 400 steel (Rotoflex)

Next the fatigue tests of Hardox 400 were carried out using ultrasonic equipment for fatigue testing at the tension-compression loading. The sinusoidal loading with the frequency about $20 \mathrm{kHz}$ and $\mathrm{R}=-1$ was used. At high frequencies specimens were cooled by distilled water with anti-corrosive inhibitor. With this approach it is possible to reach the high and ultra-high cycle region $\left(\mathrm{N} \approx 6 \times 10^{6} \div \mathrm{N} \approx 1 \times 10^{10}\right.$ cycles $)$ in times much quicker than the with use of conventional machines (NISHIJIMA K., KANAZAWA K. 1999; BATHIAS C. 2001).

Experimental material samples were made of finegrained structural steel Hardox 400 according to the dimensions and shapes shown in Figure 3.

Methods of ultrasonic fatigue testing are described in detail by Salama and Lamerand (SALAMA K., LAMERAND R. K. 1982) according to the methods discussed in (PUŠKÁR A. 1997; NISHIJIMA S., KANAZAWA K. 1999, TRŠKO L. et all 2011.). The results obtained in a Wöhler curve are shown in Figure 4.

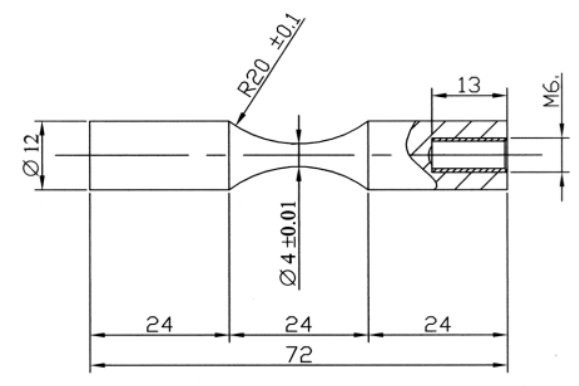

Fig. 3. Shape and geometry of the specimen used for fatigue tests at loading frequency of $\approx 20 \mathrm{kHz}$

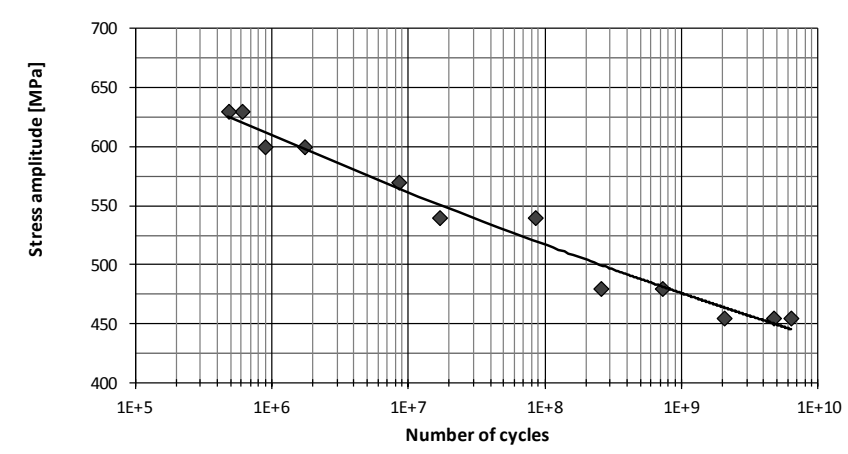

Fig. 4. Stress amplitude $\sigma_{a}$ vs. number of cycles $N$ for Hardox 400 steel $\left(f=20 \mathrm{kHz}, T=20 \pm 10^{\circ} \mathrm{C}, R=-1\right)$

\section{Discussion and conclusion}

The research conducted to facilitate responses to constructors using Hardox steel, which is a safe operation life of structural elements made of steel Hardox in terms of fatigue wear. Research was conducted in the area of $\mathrm{VC}$ on rotoflex and UHC at resonance fatigue testing machine KAUP-ZU. Results of $\mathrm{HC}$ and UHC fatigue tests are shown in Figs. 2 and 4. The continuous increase of lifetime was observed with decreasing stress amplitude. The fatigue properties of Hardox strongly depend on the Martensitic transformation conditions. The increase of the tensile strength is not accompanied by a corresponding increase of fatigue properties.

The test results (HC-rotoflex) formed a curve (Fig. 2), which clearly shows that the stress amplitude $\sigma_{\mathrm{a}}$ decreases together with an increase in cycles number $\mathrm{N}$ beyond the conventional fatigue limit $\mathrm{N}_{\mathrm{c}}=10^{7}$ cycles. Based on the obtained results the fatigue limits for Hardox 400 reached the level $490 \mathrm{MPa}$, stress amplitude decreases about $\Delta \sigma_{\mathrm{a}}=233 \mathrm{MPa}$.

Examination of the specimens (UHC) which have been made from the material analyzed showed that the 
decrease in amplitude of loads increases the number of cycles N. Stress amplitude at the level of $630 \mathrm{MPa}$ caused the fractured specimens in two trials. These cracks were created at the number of cycles accordingly 600 and 400 thousand cycles. The lowest amplitude applied at $455 \mathrm{MPa}$ resulted in cracks of three further specimens in the number of cycles above $N_{f}=2 \times 10^{9}$.

Hardox research that has been carried out confirmed the need for experimental verification of new material groups in the actual conditions of use, before applying them to the elements of machine design.

\section{Literature}

1. Asami K., Hironaga M. 1994. Effect of Shot-Peening on Suppression of Scatter of Fatigue Strength in Ti6 Al-4V Alloy. "Journal of the Society of Materials Science" Vol. 43 No. 484. p.12-17.

2. Bathias C. 2001. Designing Components Against Gigacycle Fatigue, in. Conf. Proc Fatigue in the Very High Cycle Regime, Vienna 2001, p. 97-109.

3. BATHIAS C., Bonis J. 1998. Effect on inclusions on gigacycle fatigue of a nickel base alloy. "Fracture from Defects Vol.1." - proceedings of the $12^{\text {th }}$ Bienniel Conference on Fracture - ECF 12 - held in Sheffield, United Kingdom. p.321-326.

4. Bokuvka O., Nicoletto G., Kunz L., Palcek P., Chalupova M. 2002. Low \& Hight Frequency Fatigue testing. University of Zilina, Zilina.

5. BoKůvka O., Nový F., Chalupová M., Nicoletto G. 2008. Gigacycle fatigue at high-frequency loading. "Diagnostyka" 4(48). p. 53-56.

6. DoRAZIL E. 1991. High Strength Austempered Ductile Cast Iron, Academia and Horwood, Praha and Chichester.

7. HANUS P., KONEČNÝ M. 2014. Influence of the welding process on martensitic high strength steel. Production Engineering Archives. Vol 3. No. 2. pp. 31-34

8. Koster M., Wagner G., EIFLER D. 2010. Cyclic deformation behavior of a medium carbon steel in VHCF regime. "Procedia Engineering" Vol. 2. No. 1. p. 21892197.

9. Masuda S., NishiJima S., TANAKA Y. 1986. Relationship between fatigue strength and hardness for high strength steels, “Trans. JSME” 52A. p. 847-852.

10. Mazur M., Ulewicz R., Borkowski S., Novy F. 2012. Properties of Steel Used in the Production of Semi-Trailers Car. W:SEMDOK 2012. 17th Interna- tional of PhD. Students' Seminar. 25 - 27 January, 2012. Zilina - Terchova, Slovakia. Zilina 2012

11. Naito T., UedA H., KIKUCHI M. 1984. Metal Trans., Vol.15A, pp. 1431-1436.

12. NishiJimA K., KanAZAWA K. 1999. Stepwise S$N$ curve and fish-eye failure in gigacycle fatigue. "Fatigue \& Fracture of Engineering Materials \& Structures" Vol. 22, No. 7. p. 601-607.

13. NishiJima S., Kanazawa K. 1999. Step-wise-S-N curve and fish-eye failure in gigacycle fatigue, "Fatigue and Fracture of Engineering Materials and Structures" 22, p. 601-607.

14. PUŠKÁR A. 1997. High frequency fatigue of materials, EDIS University of Zilina, Zilina.

15. RADEK N. 2012. Selected Problems of Mechanical Engineering and Maintenance. Wydawnictwo Politechniki Świętokrzyskiej, Kielce.

16. SAKAI T., TAKedA M., ShIOZAVA K., OCHI Y., NAKAJIMA M., NAKAMURA T., OgUMA N. 1999. Experimental evidence of duplex $S-N$ characteristics in wide life region for high strength steels. in: Proceedings of the Seventh International Fatigue Congress, Higher Education Press/EMAS, Beijing, China, 1999, p. 573-578.

17. SAlAMA K., LAMERAND R. K. 1982. Ultrasonic Fatigue, in. Conference Proceedings Transactions of the Metallurgical Society of AIME, New York, 1982, p. 109-118.

18. Tillová E., Chalupová M. 2009. Fatigue failure of AlSi9Cu3 cast alloy. In: Fractography 2009: proceedings of the conference with international participation held in the hotel Academia, the High Tatras, Slovakia. Institute of Materials Research of the Slovak Academy of Sciences. Košice. p. 193-196.

19. TRŠKO L., MIKOVÁ K., BOKŮVKA O. 2011. Fatigue resistance of on shore microalloyed steels for gas transport. In: Toyotarity. Heijunka. BORKOWSKI S. ULEWICZ R. (red.). Yurii V. Makovetsky, Dnipropetrovsk. p. 171-178.

\section{Acknowledgement}

The research is supported by European regional development fund and Slovak state budget by the project "Research centre of University of Žilina”, ITMS 26220220183. 